\title{
Research Note: The EU Constitution and the British Public: What The Polls Tell Us About the Campaign That Never Was
}

\author{
Paul Baines \\ Cranfield University, Bedford, UK \\ Mark Gill \\ MORI, London, UK
}

In Switzerland and the US, referendums are so ubiquitous that a highly diverse industry has spawned up around them (Bowler et al, 1996). They are now increasingly commonplace in the EU as it enlarges. Up until June 2005, Britons expected to be asked to consent or reject the proposed EU Constitutional Treaty in a national referendum but the French and Dutch no votes in their own referendums in May and June 2005 scuppered this and Britain and other EU countries paused for a period of reflection. The 'non' and 'nee' votes constituted public defiance of their governments' appeal to accept the EU Constitution, indicating how far removed the French and Dutch political elites were from the public (see Parker, 2005). But governments are often out of touch, and European leaders are no exception (Watt, 2005). Prime Minister Blair challenged British public opinion with the prosecution of the Iraq War (Baines and Worcester, 2005), as did the Swedish government when encouraging their citizens to accept the Euro (Widfeldt, 2004). In this research note, we consider British public opinion on Europe and the Constitutional Treaty, providing a summary of the referendum process along five key themes as follows:

1. A sceptical view of the Constitution: all polls showed that a majority of British people intended to vote "no" rather than "yes" in the referendum;

2. A persuadable electorate: more detailed analysis highlights the crucial importance of those who had not made up their minds and how they might affect the outcome of the vote;

3. A largely under-informed public: the lack of information about Europe that the British public possessed characterises British opinion both towards the Constitution and Europe more generally;

4. A country that sees itself distinct from Europe: perceived distinctiveness is important to understanding British public opinion on Europe; and

5. An unimportant event: the referendum campaigns failed to capture the imagination of the public.

\section{Method}

We present an overview of British public opinion towards the proposed Constitution using a series of opinion polls in the run-up to the French and Dutch votes. Analysis includes several nationally representative surveys conducted by MORI in 2004/5 on attitudes towards Europe/EU constitution for Citigroup, the Foreign Policy Centre, The Institute for Citizenship, The Observer, The Sunday Mirror and The Sun. In addition, survey research conducted by ICM, NOP, Populus and other British polling firms, as well as the regular Eurobarometer series, were all examined and related to the MORI data. We also synthesised the views of several key opinion leaders associated with the "Yes" and "No" campaigns, including a former senior executive of Britain in Europe (BIE); a spokesperson for The No Campaign; a director of a leading think tank, a member of the No 10 
Policy Unit, and a leading newspaper political editor using interpretive depth interviews. All interviews were conducted in situ, in London, lasting between 45 minutes and 90 minutes. We sought to improve the validity of the interview data by interviewing the respondents in situ (de Ruyter and Scholl, 1998), and taping and transcribing key verbatim comments and themes from the interviews (Perakyla, 1997), which are presented in the following text. Some of the interpretations we outline are shared by more than one of the various anonymous experts.

\section{Theme 1: A sceptical view of the Constitution}

British public opinion toward the Constitution was sceptical. Between April 2004 and June 2005, fourteen British opinion polls were conducted to measure public acceptance of the European Constitution in Britain. Unfortunately, several different question wordings were used hindering direct comparison of the survey results. When the UK government announced the wording that would be used in the actual referendum ballot paper in January 2005, several subsequent polls used this exact referendum wording, even though in normal circumstances such a question wording would not be acceptable in opinion research surveys. ${ }^{1}$ Despite this important distinction, the results of the surveys show a very consistent pattern. Over the fourteen month period from April 2004 to June 2005, not one opinion poll showed more people intending to vote to accept the Constitution than to reject it, as illustrated in Figure $1 .^{2}$

Nevertheless, public opinion on this issue was not static. For the second half of 2004, the momentum moved towards acceptance rather than rejection. The narrowest gap between the "yes" and "no" shares was recorded by ICM in January 2005, showing 49\% in favour compared to 51\% against ${ }^{3}$. ICM also conducted a split sample methodology on 2-3 February 2005, on behalf of Vote No, which showed the importance of the wording in referendums, although obviously artificially conducted as an opinion poll. Using the referendum question, 39\% said the UK should approve the treaty; compared with $26 \%$ who said they would vote "yes", using ICM's standard "referendum tomorrow" question". This was the high point for the "Yes" campaign. All polls conducted after January 2005 showed a steady polarisation of public opinion. The result of a survey in June 2005 by Populus ${ }^{5}$ gave similar results to the first poll on this topic in April 2004 by YouGov. ${ }^{6}$

\footnotetext{
${ }^{1}$ The government question wording used for the referendum would have been "Should the United Kingdom approve the treaty establishing a Constitution for the European Union".

2 To help comparability between these polls we have excluded from the calculations any "don't knows" and rebased the answers to give a simple "support" and "oppose" finding that equals 100\%. All results are shown using the Government style referendum question wording, with the exception of those marked with an asterisk which followed more traditional opinion poll style wordings.

${ }^{3}$ ICM interviewed 532 adults aged 18+ by telephone on 26-27 January 2005 for The Sunday Telegraph, see the following website for details: http://www.icmresearch.co.uk/reviews/2005/Sunday\%20Telegraph\%20-

\%20Opinion \%20Poll/SundayTelegraph\%20Opinon\%20Poll.asp.
}

${ }^{4}$ See ICM poll for Vote No, 3-4 February 2005. See www.icmresearch.co.uk.

${ }^{5}$ Populus poll for The Times, 3-5 June 2005. See www.populuslimited.com

${ }^{6}$ YouGov poll for The Sun, 15-17 April 2004. See www.yougov.com 
Figure 1: Proportions of the British Electorate Supporting/Opposing the EU Constitution

\section{Support and Opposition for the EU Constitution}

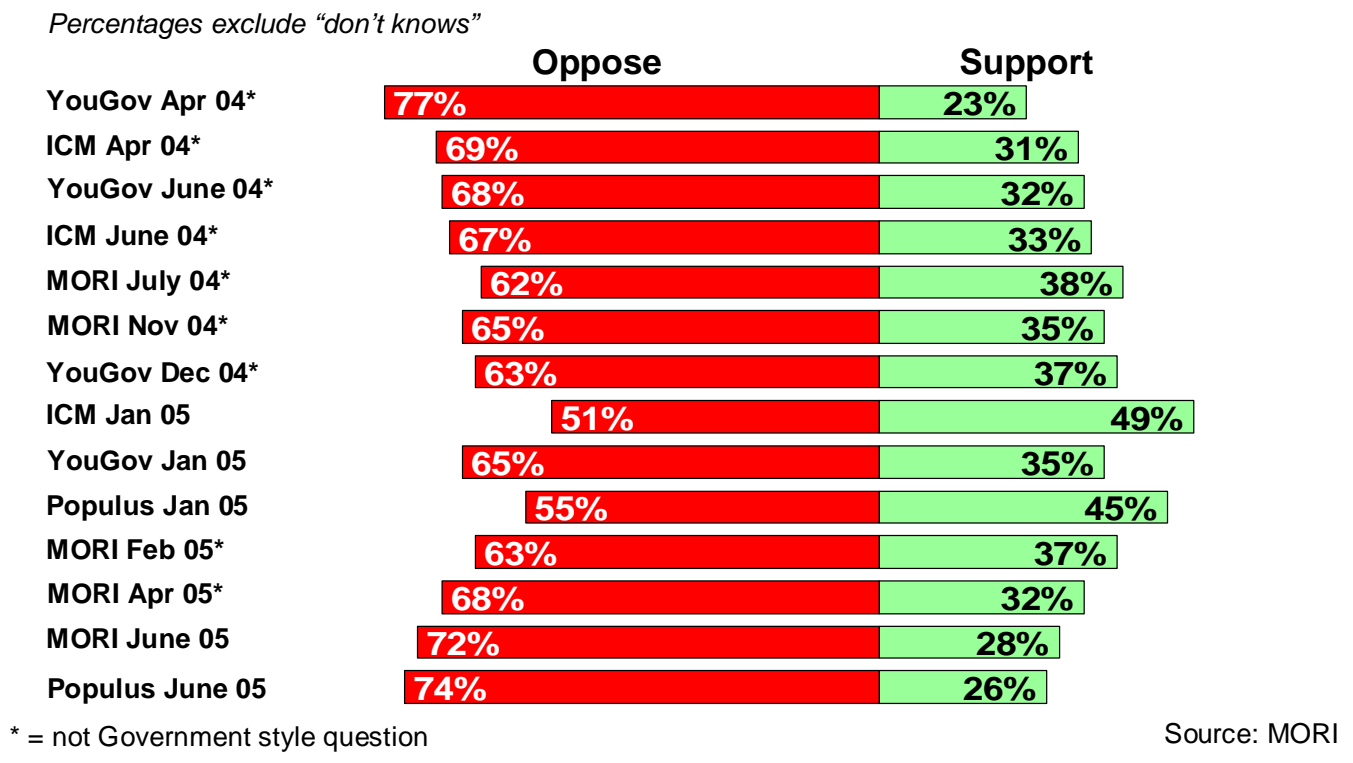

Immediately after the French referendum result, a MORI/The Sun poll found the majority of the British public were pleased with the French result (55\% pleased vs. 19\% sorry); content that the proposed Constitution was derailed. Nevertheless, as many as $67 \%$ of Britons said they still wanted a chance to vote on the Constitution, irrespective of the referendum results elsewhere ${ }^{7}$

\section{Theme 2: A persuadable electorate}

Most polls presented the results of public opinion as percentages of those supporting or opposing the Constitution, with some also showing "undecided"s or "do not care" by presenting a don't know option. However, these simple "support/oppose" formats provide no opportunity to uncover how strongly these attitudes were entrenched. Sir Robert Worcester (MORI's founder) devised a question, first developed for explaining the strength of attitudes towards membership of the EU and the Single Currency, to distinguish between those whose views on the Constitution were set and those who report themselves to be open to persuasion. It was adapted in July 2004 to determine attitudes towards the Constitution in a study conducted for Britain's Foreign Policy Centre (see Gill, Atkinson and Mortimore, 2004) and repeated on three separate occasions providing an indication of the direction of change, as well as depth of feeling, for different attitudinal segments (Table 1).

By segmenting the public in this way, we define three groups. The first are those most strongly supportive of the Constitution, not open to persuasion about changing their views. We call this group, Committed Europhiles, because their support for the Constitution appears to indicate their deepening desire for European integration. Over the period of July 2004 to April 2005, this group accounted for $9 \%$ of the adult population $(+/-1 \%)$, form the bedrock of the "yes" campaign, and is the smallest of the three key segments, remaining consistent in size throughout the period of study.

The second group are most opposed to the Constitution, holding their views so strongly that they said they were not open to persuasion. We call this group, Committed Europhobes, for the opposite

\footnotetext{
${ }^{7}$ MORI poll for The Sun See http://www.mori.com/polls/2005/s050601.shtml
} 
reason as that cited above for the Europhiles. This group was both greater in size than the first, and increased in size during the time period. In July 2004, 27\% of the British public said they were strongly opposed to Britain adopting the new European Constitution (three times the $8 \%$ who were strongly in favour). By April 2005, over a third (36\%) of Britons claimed to have made up their minds to oppose the Constitution (four times the proportion strongly in favour). The negative shift in public opinion during that time probably justifies the claim that the "No" campaign was better organised and effective in the preceding months than the "Yes" campaign.

\section{Table 1: British Attitudes and Persuadability on the EU Constitution}

Q1 Which of the following best describes your own view of whether Britain should adopt the new European Constitution? READ OUT. REVERSE ORDER

\begin{tabular}{|c|c|c|c|c|}
\hline $\begin{array}{l}\text { I strongly support Britain adopting the } \\
\text { new European Constitution (Committed } \\
\text { Europhiles) }\end{array}$ & $\begin{array}{c}\text { July } 2004 \\
\qquad \%\end{array}$ & $\begin{array}{l}\text { November } \\
2004 \\
\% \\
8\end{array}$ & $\begin{array}{l}\text { February } \\
2005 \\
\% \\
10\end{array}$ & $\begin{array}{l}\text { April } \\
2005 \\
\% \\
9\end{array}$ \\
\hline $\begin{array}{l}\text { I am generally in favour of Britain } \\
\text { adopting the European Constitution, but } \\
\text { could be persuaded against if I thought it } \\
\text { would be bad for Britain (Wavering } \\
\text { Europhile) }\end{array}$ & 23 & 22 & 21 & 20 \\
\hline $\begin{array}{l}\text { I am generally opposed to Britain } \\
\text { adopting the European Constitution, but } \\
\text { could be persuaded in favour of it if I } \\
\text { thought it would be good for Britain } \\
\text { (Wavering Europhobe) }\end{array}$ & 23 & 28 & 27 & 27 \\
\hline $\begin{array}{l}\text { I strongly oppose Britain adopting the } \\
\text { new European Constitution (Committed } \\
\text { Europhobe) }\end{array}$ & 27 & 27 & 25 & 36 \\
\hline Don't know & 19 & 15 & 17 & 8 \\
\hline In favour & 31 & 30 & 31 & 29 \\
\hline Against & 50 & 55 & 52 & 63 \\
\hline "Waverers" & 46 & 50 & 48 & 47 \\
\hline
\end{tabular}

The third group were those we classified as "waverers", split into Wavering Europhile and Wavering Europhobe groupings. They are the most important block of citizens. When they are combined, they represent the largest segment and are most susceptible to attitude change. They admit they would be prepared to change their views on the Constitution if they thought it was good or bad for Britain. In all four of the opinion polls outlined above, roughly half the general public (47\%) identified themselves as "waverers". Excluding the first survey, more of this group tended towards opposing (Europhobe group) than supporting the Constitution (Europhile group). In April 2005, 27\% were generally opposed and $20 \%$ were generally in favour of the Constitution.

Despite the fact that the opinion polls showed the "no" campaign attracting more support than the "yes" campaign, the British public reported themselves to be open to persuasion on the EU constitution, awaiting the arguments of both campaigns when a referendum date was announced, and a full referendum campaign contested. Profile analysis of the persuadable segment indicated 
they are most likely to be female, young or middle-aged (less than 55 years old), and of middle class socio-economic grouping (ABC1). Older citizens were significantly more likely to be Europhobic on the Constitution.

\section{Theme 3: A largely under-informed public}

The British public's sense of being ill-informed about the European Union, is replicated in its perceived knowledge of the Constitution. In July 2004, a MORI survey for The Institute for Citizenship found that $82 \%$ of adults felt that they did not have enough information to make a considered choice about the Constitution. ${ }^{8}$ Almost a year later, in another MORI survey for Britain in Europe $e^{9}$ just one in five people said they know a fair amount (18\%) or a great deal (1\%) about it; and just one in nine people $(11 \%)$ said they felt they had enough information to make their minds up on how to vote although in the latest MORI poll as many as $45 \%$ of the public say they held their views so strongly on the Constitution that they were not open to persuasion to change their minds!

Survey research consistently finds that the more informed a person is, or feels (s)he is, about an organisation, institution or individual, the more favourably disposed they tend to be about it. Thus, perhaps few supported the Constitution in Britain because few members of the public understood what it meant. Nevertheless, when the campaign proper began, they may have been persuaded to support it. The "No" campaign however claimed the exact opposite, that the more people know, the more likely they are to be against. The media also recognised their role in informing the public about the Constitution, although a senior journalist told the authors that the EU has more perceived weaknesses than strengths, which makes it harder to inform readers about the pro-Constitution side of the argument, although the public see the common EU passport and free trade positively. The French may be better informed than the British, since a copy of the Constitution was made available to them and they still voted no, although they may not have actually read it. A No Campaigner commented "yes" campaigners faced difficulty because the British know what they don't want from Europe but they don't know what they do want.

Many negative myths about the impact of the Constitution appear widespread. A MORI/Britain in Europe survey, conducted just before the French referendum, found that over half the British public believed that adopting the Constitution meant that the UK would: have to join the Euro $(56 \%)$, lose control over setting its own taxation ( $55 \%$ ); and lose control over its foreign policy (54\%). Incredibly, one in four Britons agreed that if UK approved the Treaty, it would mean "The Queen will no longer be Head of State"10.

\section{Theme 4: A country that sees itself distinct from Europe}

Latest Eurobarometer surveys record 62 per cent of Britons as thinking of themselves as "British not European", the highest level among the EU15 average of 40 per cent (Eurobarometer, 2003). In the same survey, 55 per cent of Britons declared themselves "very proud to be British", compared to the French and Germans who recorded 38\% and 19\% respectively on this item. When questioned in a MORI poll for The Institute for Citizenship, only 1 in 10 Britons $(10 \%)$ felt that Britain needs the EU more than the EU needs it. 1 in 3 Britons (32\%) felt that the EU needed Briton more than vice versa and another 1 in 3 Britons (32\%) felt that they needed each other equally. 1 in 7 Britons (14\%) felt that the two institutions could do without each other altogether. Britons feel 'superior' to the EU. This feeling of distinctiveness perhaps goes some way in explaining the greater support for the principle of a Constitution for the European Union, when measured by the Eurobarometer surveys.

\footnotetext{
${ }^{8}$ MORI research for The Institute for Citizenship, www.mori.com/polls/2004/ifc.shtml

${ }^{9}$ MORI research for Britain in Europe (June 2005).

${ }^{10}$ See http://www.britainineurope.org.uk/
} 
These findings do not contradict the polling by the British pollsters (as illustrated in Figure 1), instead they reinforce the argument that many Britons believe that what applies to a "distant" Union does not necessarily have an impact in their own country.

\section{Theme 5: An unimportant event:}

Generally, the British people do not want more integration with Europe and more political decisions being taken by Europe (Eurobarometer, 2005), at least partly because they feel that Europe has little relevance in their lives, and does not make policy and law in the interests of the British people. The British public's acceptance that it has a low degree of knowledge of Europe's political institutions has several implications. First, it may lead to an underestimation of the EU's real importance, thereby reducing the issue's salience (and feeding a vicious circle of further reluctance to find out more about it). This is recorded in MORI's regular tracking of the public's perception of the most important issues facing the country. Europe is rarely seen as one of the top half a dozen key issues for the nation, decreasing markedly since early 2003 in salience compared to other issues. MORI data for July 2005 showed $7 \%$ of the public saying Europe was one of the most important issues, making it joint $9^{\text {th }}$ highest along with the environment and poverty/inequality. It was at its highest in June 2005 after the budget row between Prime Minister Blair and President Chirac which saw 19\% of the public citing Europe as a key national issue. Indeed, more people thought Europe was an important issue at this point than they did during the European Parliament elections in June 2004 $(16 \%) .{ }^{11}$ Second, low knowledge may imply a low level of engagement with European political institutions, and low turnout at European elections, and perhaps at referenda. The UK's record of participation in European elections is clear evidence of this happening (24\% turnout in 1999, easily the lowest of the EU 15 nations and substantially lower than the EU average of 49\%; with an increase to $39 \%$ in 2004 through a combination of all-postal ballots and combining with local elections in some regions).

\footnotetext{
${ }^{11}$ MORI Political Monitor http://www.mori.com/polls/trends/issues.shtml
} 
Figure 2: Europe's Perceived Impact on the British Public

From this list which two or three of the following do you believe have the most impact on people's everyday lives? You can select up to three options

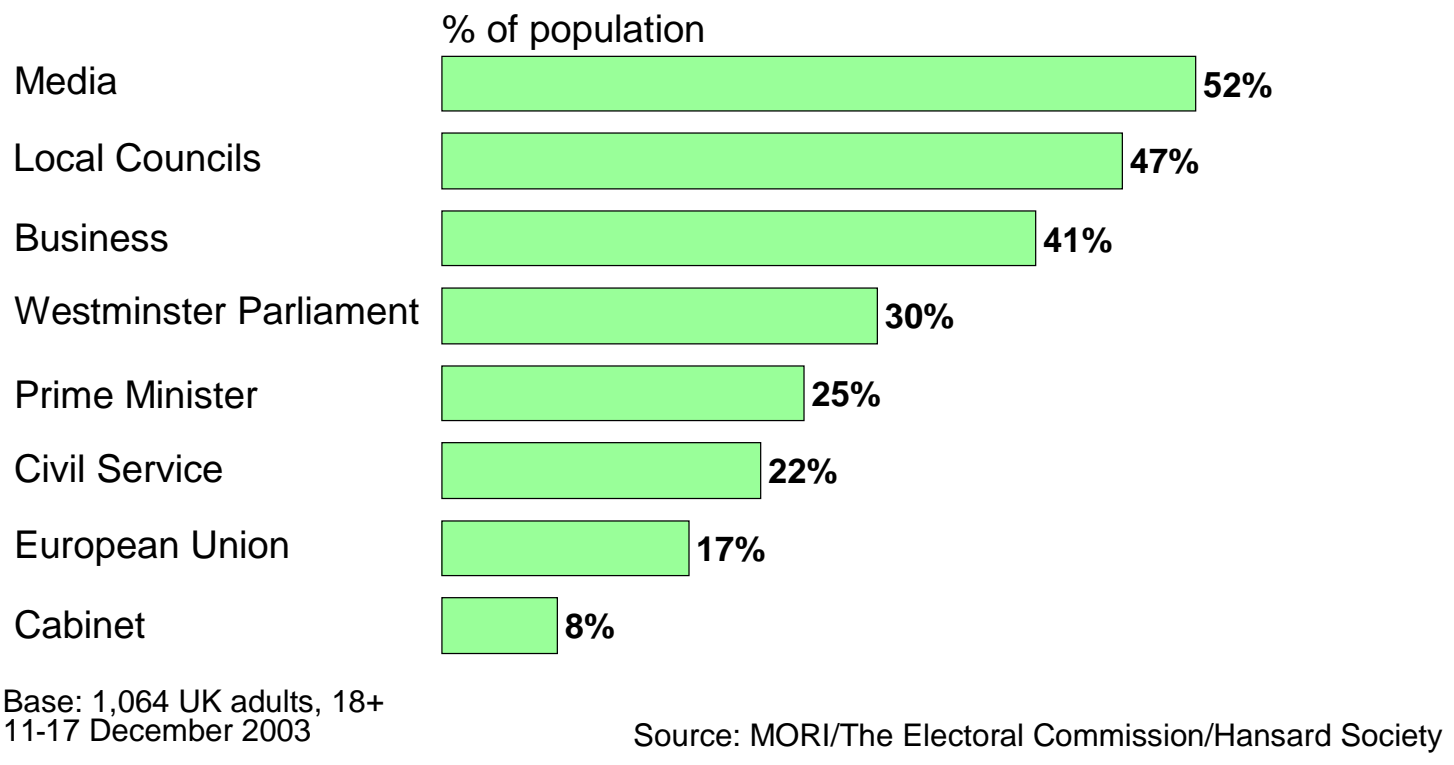

The idea that Europe is not an important issue reflects a perception that the EU itself is not important. In MORI's Audit of Political Engagement survey at the end of 2003, the European Union is seen as having less impact on people's everyday lives than either national or local political institutions, and less than the media and business, as illustrated in Figure 2. ${ }^{12}$ It may be equally that Britons perceive the Euro to be equally irrelevant to their lives, since the British economy has done well outside it, and this may have given the British more self-confidence in their Eurosceptic nature as a result, according to the No Campaign spokesperson.

Discussion: implications for understanding opinion on the referendum

Opinion poll data and analysis goes only so far in understanding how the British public would have voted in a referendum on the EU Constitution. The public take actual voting in elections or referenda more seriously than they do when giving answers to opinion pollsters. Despite this, our article aims to highlights three key implications for any future European-related referendum campaign:

Implication 1: The need to convince the public of the importance of the decision

One key argument of the "yes" campaign was that if the British public believed voting against the Constitution meant a renegotiation of Britain's membership, or withdrawal from the Union, that this would lead to a upsurge in support for the Constitution. This theory was premised on the belief that most other European countries would have ratified the Constitution before the UK voted and, thus, the British "yes" campaign would benefit from a domino effect. If only Britain rejected the Constitution, the "no" campaign would then have had to explain the consequence of Britain being the only country to reject the Constitution. In this scenario, many "yes" campaigners believed this would have exposed a division within the "no" camp: 1) those who would argue that a UK "no" would mean the failure of the Constitution and 2) those who wanted to use this as an opportunity for Britain to withdraw from the Union. A No.10 spokesperson believed that the many Britons

12 Source: Audit of Political Engagement (The Electoral Commission/Hansard Society). Fieldwork December 2003; published March 2004. See http://www.electoralcommission.org.uk/templates/search/document.cfm/9273 
would prefer to vote for an unloved constitution and the "status quo" rather than face the possibility of exclusion from the EU.

MORI's July $2004^{13}$ survey provides prima facie evidence that the hypothesis outlined above has some validity. More of the British public support membership of the EU (50\%) than oppose it (41\%), and significantly more favour membership than favour the Constitution. In contrast, the public were, on balance, opposed to participation in the Single Currency (36\% in favour vs. $56 \%$ against) and so there would have been little mileage in linking the Constitution with the Single Currency for the "yes" campaign. The more valuable analysis, however, is to examine how views on all three of these issues interrelate.

Among those who were strongly against the Constitution, three quarters (74\%) had also decided against the Single Currency and, somewhat fewer but still, $62 \%$ were strongly against British membership of the EU. This finding has profound implications - the majority of those most committed against the Constitution were not opposed to it on some matter of detail nor was their opposition based on the principle of having a Constitution or not. They were opposed to it on the very principle of British membership of the EU. This evidence suggests there is, in theory at least, the possibility of breaking the "strongly opposed" to the Constitution bloc by a campaign which persuaded them that a "no" vote would lead to Britain leaving the EU, but perhaps not in sufficient numbers to guarantee a victory. If this same proportion of those strongly against the Constitution were strongly against EU membership (62\%) in the latter April 2005 MORI poll, this would equate to at least four in ten of the British public who could be counted on to turn out and vote against the Constitution no-matter what the consequences for Britain as they are in principle opposed to British membership of the Union in the first place.

\section{Implication 2: Segmentation is key}

Segmentation of likely voters based on their self-reported persuadability is fundamental in referendum campaigns. Through this we learn two important facts:

i) That even when a large proportion of the public say they are open to persuasion, as the British did despite their Euro-scepticism, the importance of the referendum campaigns become paramount.

ii) Among those committed to a position on one of the three European questions, they are more likely to be committed to a Euro-sceptical (Europhobe) than a Europhile position, especially with regards to the Constitution or the Single Currency. This provides any No Campaign with a much more comfortable position from which to begin a campaign.

It becomes imperative to examine the waverers' views on the Constitution in terms of their attitudes towards EU membership. The majority were also wavering on EU membership (82\%). In contrast to their views on the Single Currency, Constitution waverers were much more likely to be strongly in favour of membership of the EU (14\%) than strongly opposed (3\%). As such, very few waverers are committed opponents to the Union. Crucially, this means that there is a qualitative difference between the majority of strong opposers of the Constitution and those who are generally opposed but might change their minds. They differ not just in the strength of their views on the Constitution, but on their whole approach to Europe. Two-thirds of the committed opponents are anti-EU in principle, whilst the same is true of only a tiny proportion of waverers.

\footnotetext{
${ }^{13}$ This survey asked respondents about their attitudes towards the Constitution, the Single Currency and membership of the Union, thus allowing cross-analysis of responses.
} 
The implication for referendum campaigners is clear: the majority of strong opponents cannot be treated as a more severe version of those who are generally opposed. They must be recognised as a different species, and any desire to turn the Constitution (or for that matter the Single Currency) referendum into a referendum on Britain's membership of the EU would likely enthuse this group to go out and vote, rather than to stay at home or even change their minds.

\section{Implication 3: Timing and domestic considerations}

The leaders of The Yes Campaign believed that had the government offered its support, "early in the first Blair government", they might have won a referendum on the Single Currency but the absence of clear leadership from government made it difficult to raise funds and develop promotional campaigns. Conversely, The No Campaign could equally have entrenched the Europhobic attitudes of those over 55 years old, who we know from British general elections, outnumber those under 34 years old by two to one, and are twice as likely to vote in British general elections (Worcester, Mortimore and Baines, 2005). The French and Dutch referendums were regarded by some commentators as more a test of their government's domestic popularity rather than their policies on Europe (Bickerton, 2005; Thornhill and Peel, 2005). The referendum results in Holland and France were an indication of their governments' unpopularity, according to Yes campaigners. A key question for government political strategists was whether this would equally be the case in Britain. A No.10 spokesperson suggested that the antithesis would be that in Britain the campaign would have been fought on the issues of Britain's role in Europe and the world, not a referendum on Blair's premiership, especially if UK was one of the last to vote on the issue.

How the public regard the status quo or the "safe" option is important to the success of any referendum campaign. The determination of this fixed point position is important to political strategists, and represents a political 'line in the sand', from which to benchmark their campaigns. Some in The No Campaign were confident of success because they felt Britons would see the Constitution as a step-change to greater integration. Some in The Yes Campaign were equally confident of success, as they imagined that Britain's position in Europe would be put in jeopardy should it be the only, and last, country to reject the Constitution. Either way, how a government approaches the issue at least partly depends entirely on how popular it is at the time a referendum campaign is rolled out. An important lesson for future referendum campaigners, according to Yes Campaigners, is the strategic importance of timing, or what marketers refer to as "strategic windows" (Abell, 1978).

\section{Concluding Remarks}

It is important to understand the underlying reasons for attitudes and opinions of the general public towards referendums because the public take referendums more seriously than opinion polls. They consider their positions more carefully, and are likely to maintain the status quo if they perceive that there are risks to changing the situation. The marketing task for any referendum campaign which seeks to alter the status quo is to assuage public fears over such risks. Conversely, a referendum marketing campaign which seeks to maintain the status quo can equally play on public fears of what 'will' happen in the event of change. In both cases, this status quo position, and exactly how that is constituted in the public mind, serves as a benchmark for the referendum campaigns. In relation to the British EU Constitution, whilst those opposed were a larger group than those in support, a majority of the public reported themselves to be open to persuasion. Careful targeting in campaigning may have turned the campaign either way, especially if a popular government had wholeheartedly supported a Yes campaign, with arguments proposed about the importance of the future membership of Europe. Cynics would say that Prime Minister Blair carefully sidestepped the Constitution issue by refusing to set a date for the British referendum until after it had been ratified 
or otherwise by other key member state governments. He clearly understood well the strategic importance of timing in referendums and the public's reluctance to alter the status quo.

\section{Acknowledgements}

The authors would like to thanks Sir Robert Worcester and Dr. Roger Mortimore for their helpful comments on a draft of this paper.

\section{References}

Abell, D.F. (1978), "Strategic windows", Journal of Marketing, July, pp.21-26.

Baines, P. and Worcester, R. (2005), "When the British Tommy went to war, public opinion followed", Journal of Public Affairs, Vol.5, No.1, pp.4-19.

Bickerton, J. (2005), "Dutch find 20 reasons to reject EU treaty", The Financial Times, 2 June.

Binzer Hobolt, S. (2005), "When Europe Matters: The Impact of Political Information on Voting Behavior in EU Referendums", Journal of Elections, Public Opinion and Parties, Vol.15, No.1.

Bowler, S.; Donovan, T. and Fernandez, K. (1996), "The Growth of the Political Marketing Industry and the California Initiative Process", European Journal of Marketing, 30, 10/11, pp.173-185.

Denzin, N.K. and Lincoln, Y.S. (2000), "Introduction: the discipline and practice of qualitative research, in Denzin, N.K. and Lincoln, Y.S (eds.), Handbook of Qualitative Research, $2^{\text {nd }}$ Edition, Sage Publications, London.

Electoral Commission (2003/4), Audit of Political Engagement Survey, London: Electoral Commission, available at: www.electoralcommision.org.uk

Eurobarometer (2003), Report 59: Conducted March - April 2003, http://europa.eu.int/comm/public opinion/archives/eb/eb59/eb59.1 uk.pdf, accessed on $18^{\text {th }}$ August 2005.

Eurobarometer (2005), Report 64: Conducted October - November 2005, http://www.europa.eu.int/comm/public_opinion/archives/eb/eb64/eb64_uk_nat.pdf, accessed on $17^{\text {th }}$ February 2006.

Gill, M.; Atkinson, S. and Mortimore, R. (2004), The Referendum Battle, London: The Foreign Policy Centre (fieldwork for survey conducted among 1,063 GB adults, 22-27 July 2004)

Parker, G. (2005), "Referendums that threaten to undermine European Unity", The Financial Times, $14^{\text {th }}$ April.

Perakyla, A. (1997), "Reliability and Validity in Research Based on Tapes and Transcripts". In Qualitative Research: Theory, Method and Practice, edited by Silverman, D., London: Sage Publications, pp.201-220.

de Ruyter, K. and Scholl, N. (1998), "Positioning qualitative market research: reflections from theory and practice", Qualitative Market Research: An International Journal, Vol. 1, No. 1, pp. 7-14.

Thornhill, J. and Peel, Q. (2005), "Delors decries No camp for confusing local with EU issues", The Financial Times, 25 May.

de Vreese, C.H. and Semetko, H.A. (2004), Political Campaigning in Referendums: Framing the Referendum Issue, London: Routledge.

Watt, N. (2005), "Resounding no shocks European leaders", The Guardian, $2^{\text {nd }}$ June.

Widfeldt, A. (2004), "Elite collusion and public defiance: Sweden's Euro referendum in 2003", West European Politics, Vol.27, No.3, pp.503-517.

Worcester, R; Mortimore, R; and Baines, P. (2005), Explaining Labour's Landslip, London: Politicos Publishing.

\section{Surveys Cited}

Citigroup/MORI (10-15 February 2005), EMU Entry and EU Constitution, available at: http://www.mori.com/polls/2005/citigroup-feb.shtml 
MORI survey presented at the 2005 Konigswinter Conference May 2005. Fieldwork for surveys were 19-25 April 2005(Germany) and 6-10 May (UK). Data available from authors on request.

Britain in Europe / MORI (27-29 May 2005), Attitudes towards the EU Constitution. Data available from authors on request.

MORI Political Monitor, (1992-present) (trends on most important issues facing Britain) www.mori.com/polls/trends/issues

Sunday Telegraph / ICM (26-27 January 2005), available at: www.icmresearch.co.uk

The Financial Times / MORI (10-15 April 2003), State of Britain Survey 2003, available at: http://www.mori.com/polls/2003/mpm030415-top.shtml\#q20

The Institute for Citizenship/MORI (12-16 August 2004), UK on Europe, Low on Knowledge, Low on Trust, available at: www.mori.com/polls/2004/ifc.shtml

The Observer/Sunday Mirror/MORI (28-29 April 2005), Election Research-Poll2, available at: http://www.mori.com/polls/2005/obs050429.shtml

The Sun/MORI (1 June 2005), Attitudes Towards the EU Constitution, available at: http://www.mori.com/polls/2005/s050601.shtml

The Sun/YouGov (15-17 April 2004), available at: www.yougov.com

The Times/Populus (3-5 June 2005), available at: www.populuslimited.com

Vote No/ICM (3-4 February 2005), available at: www.icmresearch.com

Weber Shandwick /MORI (15-20 January 2004), Europe Research Among UK Residents, available at: http://www.mori.com/polls/2004/weber.shtml

\section{Biographical Notes}

Dr. Paul Baines is Principal Lecturer in Marketing at Middlesex University Business School. He has published over forty journal articles and conference papers on political marketing issues. He is a coauthor and co-editor of texts on marketing research, strategic marketing, PR and Public Opinion.

Mark Gill is Head of Political Research at MORI. He leads on MORI's political research for the media and non-governmental organisations in Britain. He regularly appears on radio and television commentating on British politics.

\section{Address correspondence to:}

Dr. Paul Baines, Cranfield University, Bedford, UK, email: prbaines@al11ss.fsnet.co.uk \& to Mark

Gill, MORI, 79-81 Borough Road, Borough, London, UK, email: mark.gill@,mori.com. 